\title{
Development of software for analysis of indicators of spatial development of a complicated subject territory
}

\author{
Alexander Sizov ${ }^{1}$ and Elena Chernykh ${ }^{2, *}$ \\ ${ }^{1}$ Moscow State University of Geodesy and Cartography, 105064, Moscow city, Russia \\ ${ }^{2}$ Industrial University of Tyumen, 625001, Tyumen city, Russia
}

\begin{abstract}
The article is devoted to the description of the created software package that allows the user to solve a number of problems of systematization and primary processing of a large volume of spatial data on three subjects of the Tyumen region included in the statistical register of Rosstat for a given monitoring period in order to calculate and analyze indicators of the spatial development of the territory of the "Greater Tyumen region"
\end{abstract}

\section{Introduction}

To develop software and display spatial data, the MapInfo geographic information system (GIS) was chosen to collect, store, display, edit and analyze data. GIS MapInfo is one of the most widespread GIS in the world, containing, like any universal system, an insufficient number of ready-made tools for solving practical, narrowly focused tasks of various profiles. To solve such problems, there is a number of software technologies created for the development of solutions to specialized problems in the MapInfo environment. One of such technologies is the MapBasic programming language for MapInfo GIS.

The software package for the analysis of indicators of the spatial development of the territory of a complex subject was developed using the MapBasis programming language for MapInfo GIS and named "ANDANTE 1.0" (Data Analysis by Territory). As a topographic basis, the author digitized the map of the "big" Tyumen region, as well as maps of the subjects of maintenance, and created the following thematic layers: the administrative division of the "big" Tyumen region into subjects of the Russian Federation, the administrative division of each subject into municipal districts, the lands of settlements and agricultural land for each constituent entity of the Russian Federation, as well as layers of hydrography of the "big" Tyumen region. The created layers contain the analyzed information and are used to construct diagrams, as well as visual display of cartograms, visually showing the intensity of any indicator within the territory on the map.

\footnotetext{
*Corresponding author: chernyheg@tyuiu.ru
} 


\section{Methodology}

Considering that the lands of settlements and agricultural lands are among the main consumers of the invested funds, and the balance of these lands, for various reasons, changes over time, there is a need for generalized information on these lands from the USRN.

The created software package allows the user to solve a number of problems of systematization and primary processing of a large volume of spatial data for three subjects of the Tyumen region included in the statistical register of Rosstat for a given monitoring period in order to calculate and analyze indicators of spatial development of the territory of the "Big Tyumen region". In addition, the software package uses an established template in the form of data presentation, correlating the types of economic activities of three subjects: the South of the Tyumen region, Khanty-Mansiysk and Yamal-Nenets Autonomous Okrug, land areas of settlements and agricultural lands. The data is processed according to a given algorithm, including filtering (exclusion) processes from the general array of records for all subjects with signs of formal errors.

A distinctive feature of the processing algorithm is the accounting and adjustment of the conditionally active period of the land reform implementation, which displays a system of indicators for the spatial development of the territory, based on a generalized analysis of the initial data on the state and use of land in the Tyumen region for the period from 1990 to 2019. An increase in the billing period for the long term is possible.

The software package also implements the possibility of an analytical comparison of the subjects of the Tyumen region in the context of administrative districts for various indicators of national economic activity to confirm the disequilibrium of the economy.

The software package contains four modules, which are connected by pressing the corresponding button in the menu of the software package as additional programs in the GIS MapInfo (Fig. 1):

- Module 1 "Development of territories in a complex subject";

- Module 2 "System of a complex of indicators of spatial development of the territory (for each constituent entity of the Tyumen region)";

- Module 3 "The system of multi-stage assessment of indicators of spatial development of the territory, reflecting the specifics of a complex subject";

- Module 4 "Comparative analysis of the environment-forming potential of the territory of the Tyumen region after the land reform."

Let's consider the operation of the software package using the example of modules 1 and 2 .

\subsection{Module 1 "development of territories in a complex subject"}

Calling Module 1 causes a window to appear that allows you to select the parameters for analyzing the stability of the economy of a complex entity (Fig. 2). Analysis and evaluation are carried out on the basis of data entered into thematic tables (DB) of the MapInfo GIS environment according to:

- investments in fixed assets;

- revenues of the local budget actually executed;

- expenses of the local budget, actually executed;

- shipped goods of own production (thousand rubles);

- indices of agricultural production;

- costs of environmental protection;

- the number of objects with stationary sources of pollution. 


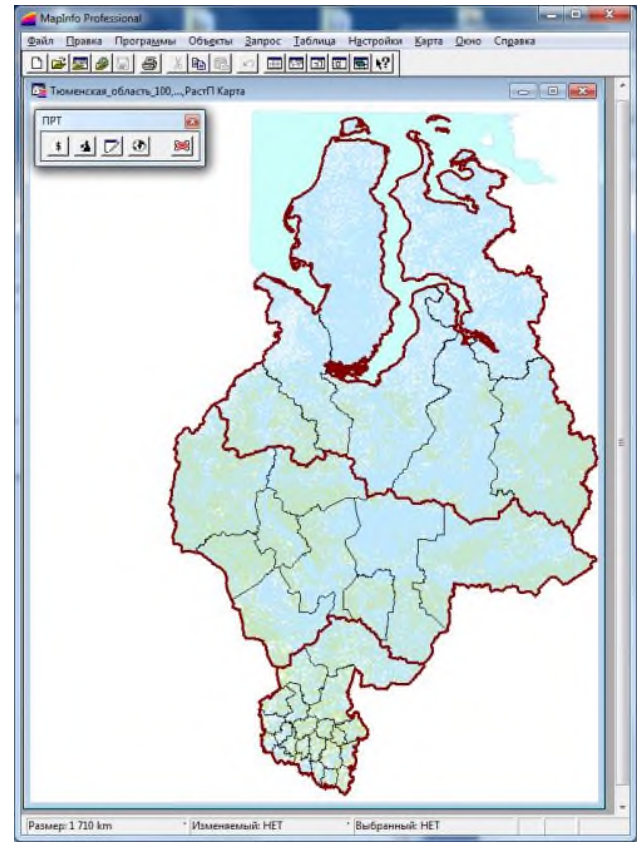

Fig. 1. A complex subject "large" TO with data processing modules.

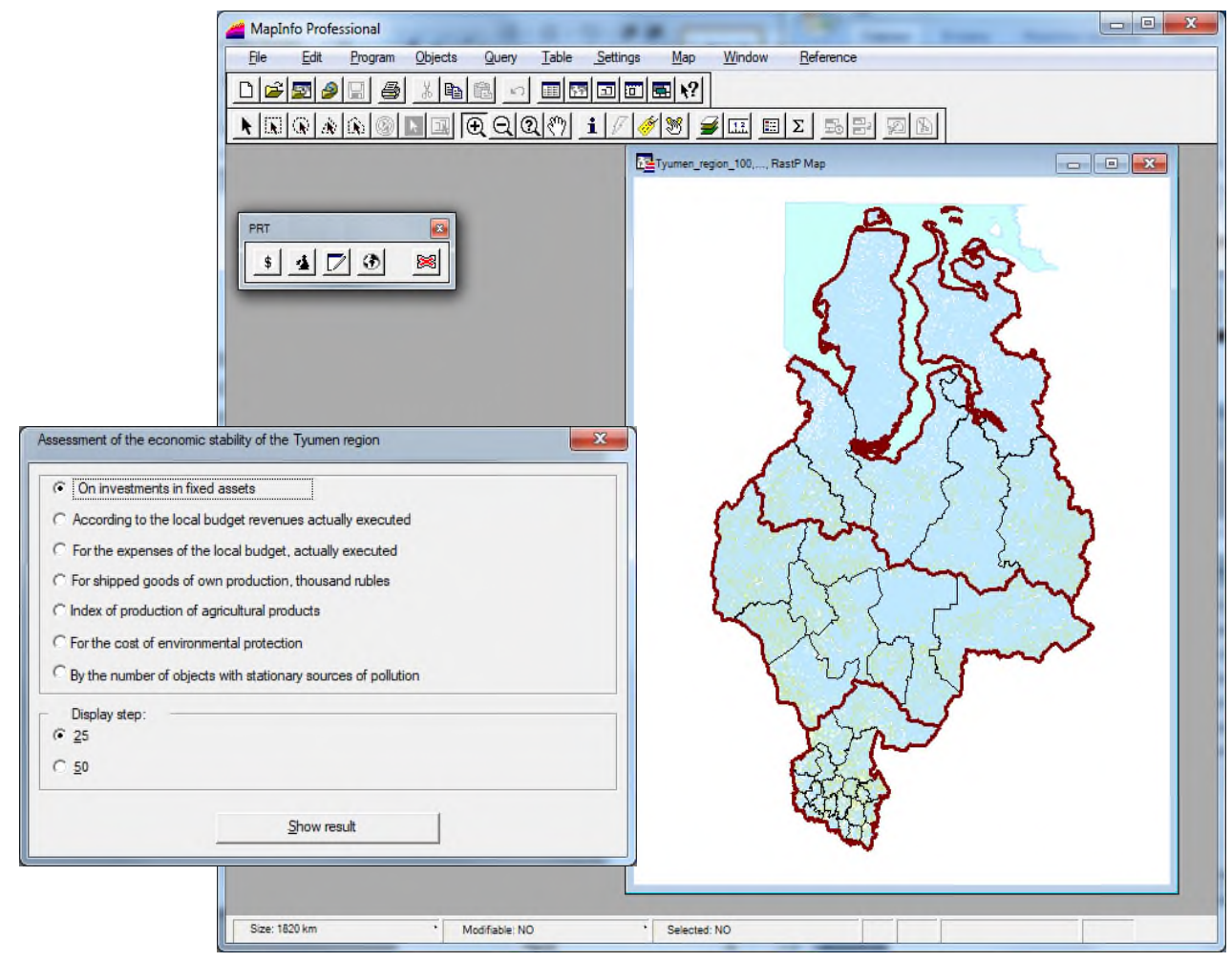

Fig. 2. Complicatedly arranged subject "large" TO with the display of the first data processing module. 
After pressing the button "show the result" for the selected indicator, a cartogram is built, visually reflecting the intensity of each indicator within the territory on the map.

These indicators were chosen to confirm the judgment about the disequilibrium of the economy of the "Big" regions of the Tyumen region according to the following data: current costs of environmental protection, shipped goods of own production, the number of objects with stationary sources of pollution, the index of agricultural production, investments in fixed assets, incomes and expenses of the local budget actually executed.

Figures 3-8 show cartograms built on the basis of generalized data entered into the MapInfo GIS database by the "big" TO.

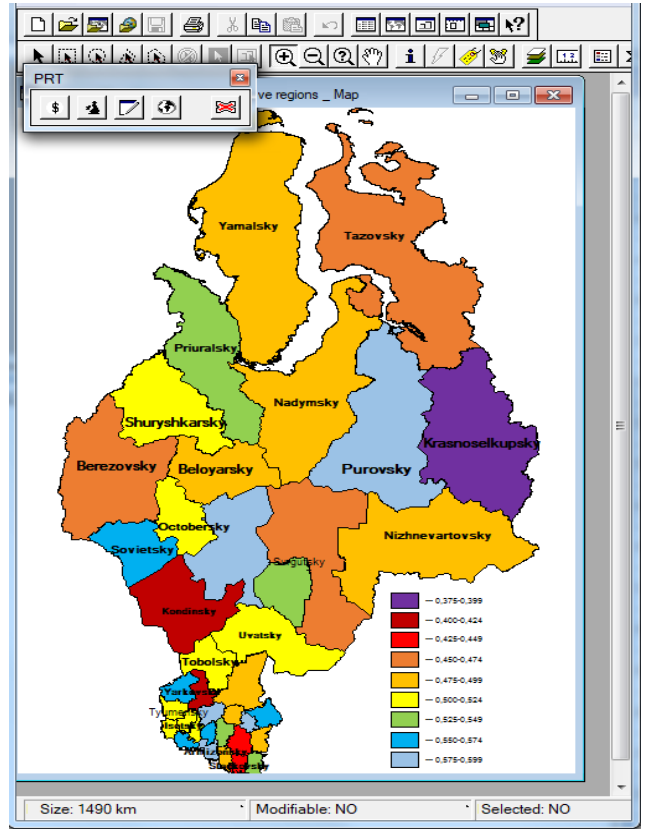

Fig. 3. Zoning of the territory of a "large" TO by investments in fixed assets.

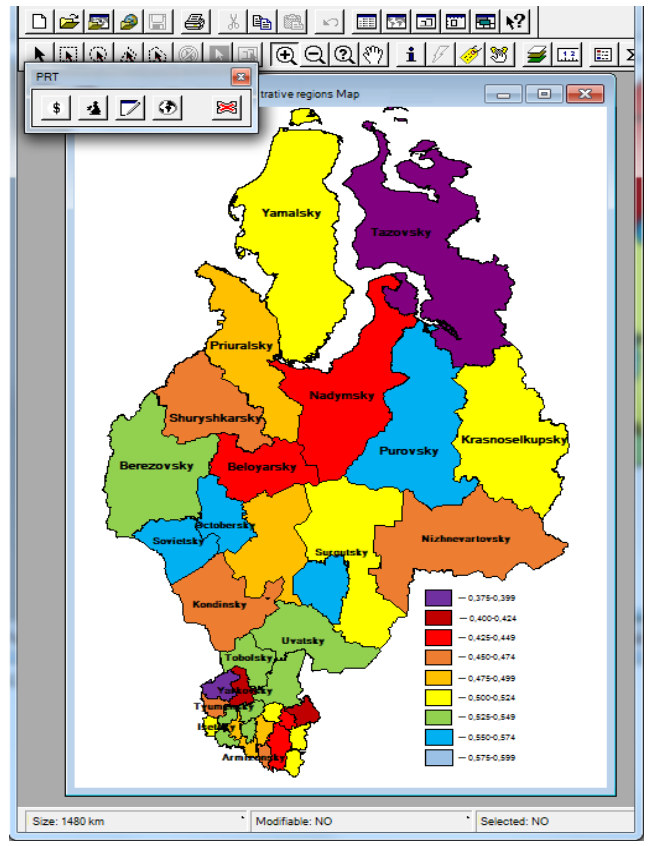

Fig. 4. Zoning of the territory of a "large" TO by local budget revenues actually executed. 


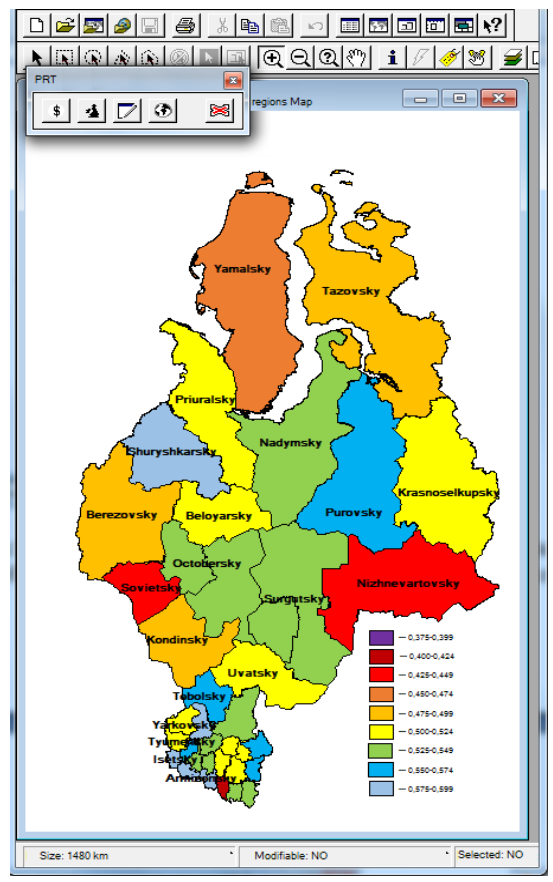

Fig. 5. Zoning of the territory of the "large" TO by goods shipped.

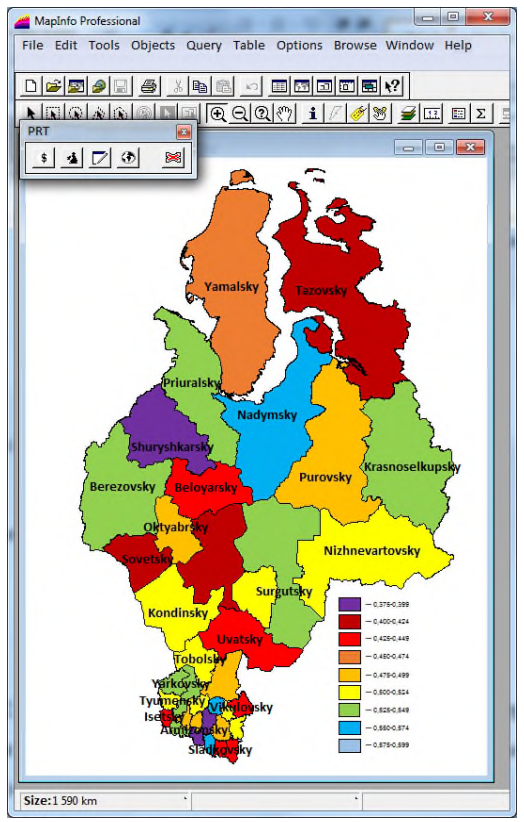

Fig. 7. Zoning of the territory of "large" TO in terms of environmental protection costs.

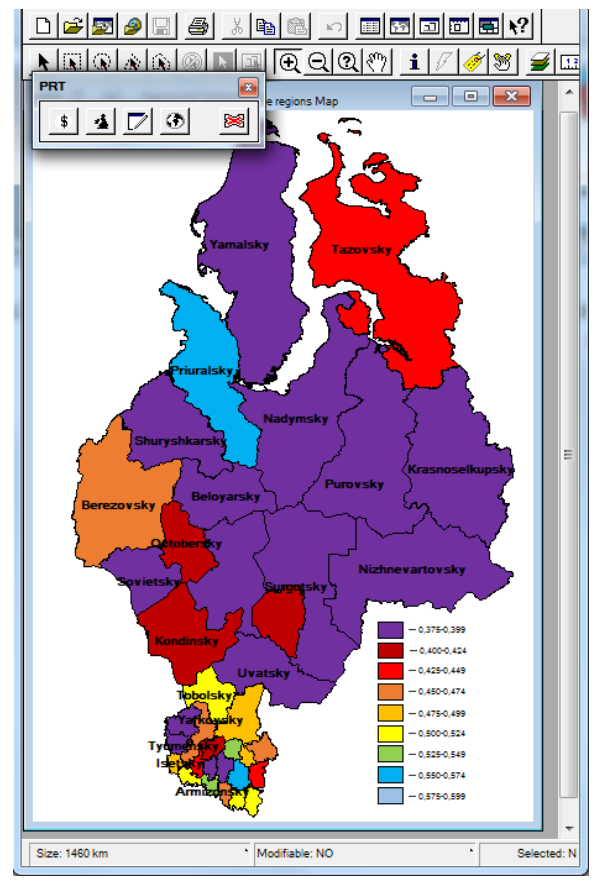

Fig. 6. Zoning of the territory of "large" TO by indices of production of products of own agricultural production.

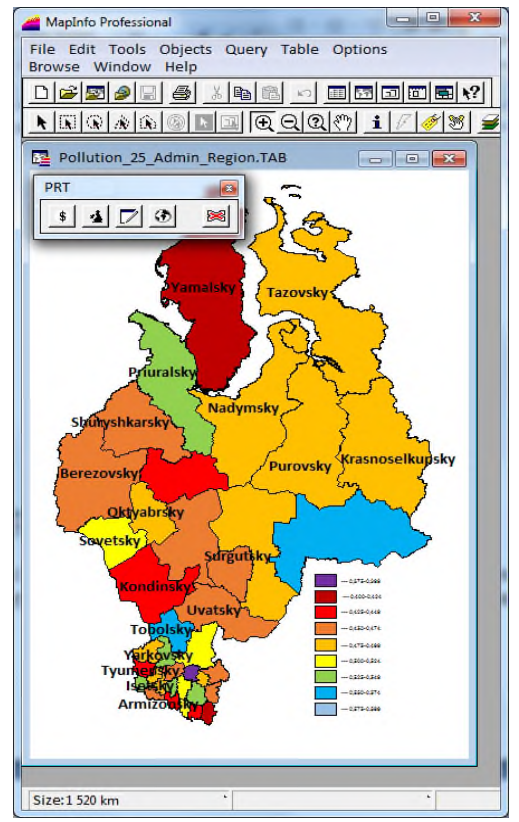

Fig. 8. Zoning of the territory of a "large" TO by the number of facilities with stationary sources of pollution.

According to the dynamics of indicators, such as: investments in fixed assets, current expenses for environmental protection, goods of own production were shipped, the number 
of objects with stationary sources of pollution, the index of agricultural production, revenues and expenditures of the local budget, actually executed, the districts included in the the composition of the "Big" Tyumen region, differ significantly and have varying degrees of stability, which was established by the Hirst method.

None of the indicators and their combination in the period under review (2008-2018) returned to the previous state, which indicates the disequilibrium of processes in the economy.

Thus, it can be argued that the Tyumen region, exchanging significant flows of resources with the environment, is characterized as an open system with its own peculiarities of territory management in a complex subject.

\subsection{Module 2 "System of a complex of indicators of spatial development of the territory (for each constituent entity of the Tyumen region)"}

Considering that the lands of settlements and agricultural lands are subject to special accounting, it becomes clear that the analysis of indicators of the spatial development of the territory is impossible without taking into account the dynamics of these lands.

During the period of land reform (1990-2008), these lands have undergone significant changes in the quantitative and qualitative state. The tasks of analyzing the state of these lands, solved in the program, are becoming especially relevant now. It is on these lands that all the processes of land reform are clearly reflected and it is these lands that are the main consumers of the invested funds, therefore, the change in the balance of these lands significantly affects the economy of not only municipal districts, but also the subjects of the Russian Federation.

Calling Module 2 demonstrates the appearance of a window that allows you to select the parameters of the analysis of the spatial development of the territory (Fig. 9). The analysis of the complex of indicators of the spatial development of the territory is carried out both for each subject included in the TO and for the complex subject of the "large" TO on the basis of the data entered in the thematic tables (DB) of the MapInfo GIS environment. The program analyzes the following indicators:

- indicator of dynamics and speed of dynamics;

- indicator of urbanization (development) of land and indicator of the rate of urbanization;

- indicator of agricultural land development and indicator of the rate of agricultural land development;

- indicator of naturalization of land and indicator of the rate of naturalization

of land. 


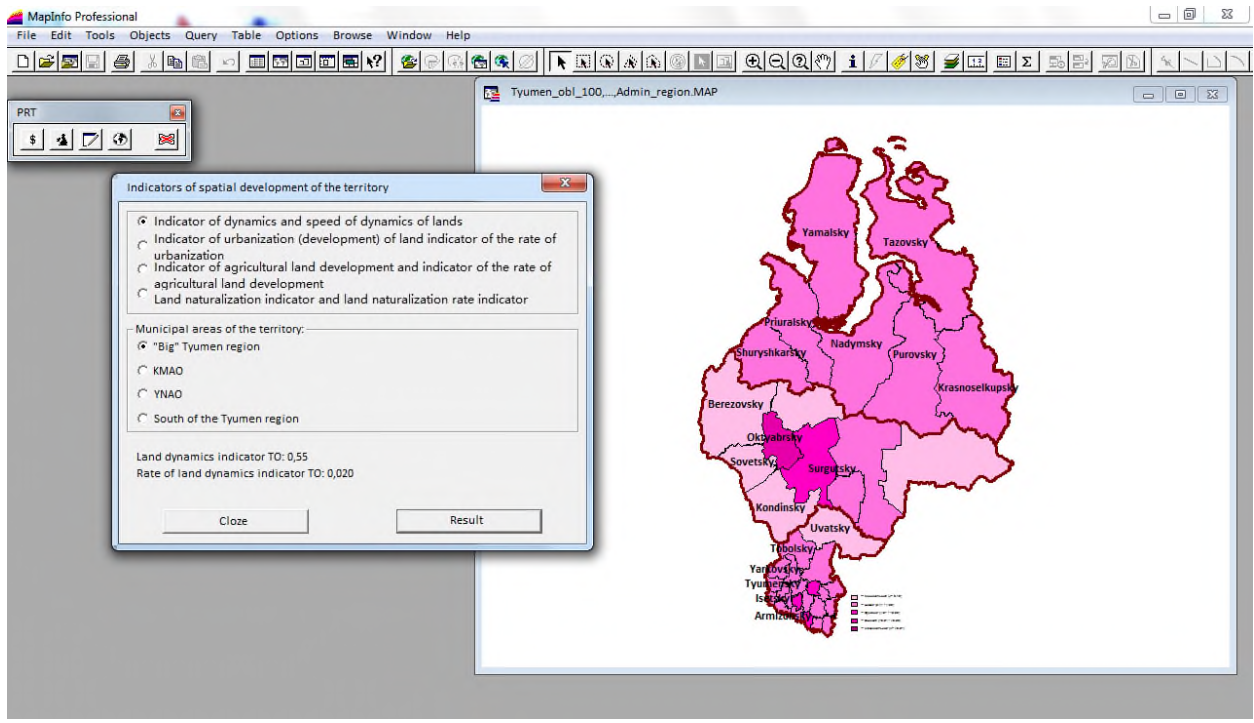

Fig. 9. Complicated subject "large" TO with the display of the zoning of the territory according to these indicators of dynamics and speed of dynamics of land.

By clicking on the "Show result" button, a cartogram is built for the selected indicator, visually reflecting the intensity of each indicator within the selected territory. Also in the presented dialog box, you can see the calculated indicators of land dynamics and the speed of land dynamics.

Figures 10-12 show cartograms built on the basis of generalized data entered into the MapInfo GIS database in terms of the dynamics and speed of land dynamics for each subject.

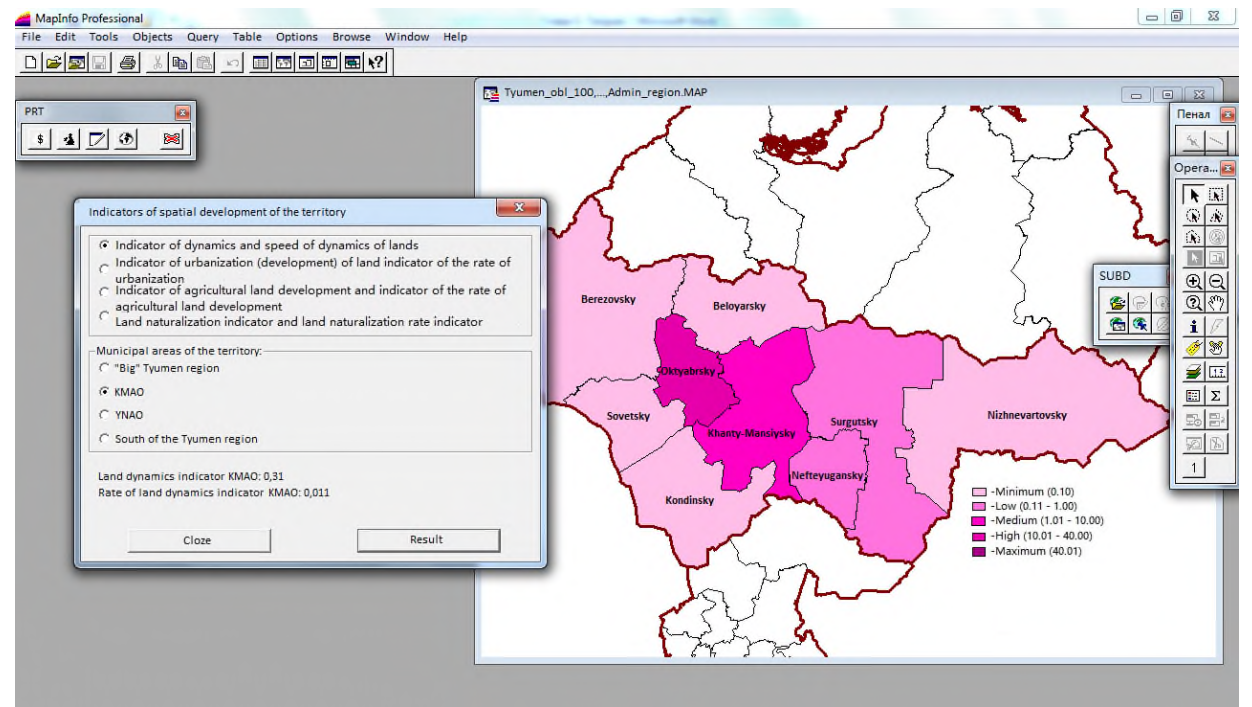

Fig. 10. Zoning of the territory according to the indicator of dynamics and the rate of dynamics of land in municipal districts of KhMAO-Yugra. 
As can be seen from the cartogram, the Oktyabrsky District is the "leader" in the KhantyMansi Autonomous Okrug in terms of the dynamics of the land speed (2.30\%). The lowest rate of land dynamics is observed in the Beloyarsk municipal district.

In the Yamalo-Nenets Autonomous Okrug, the situation is very stable in terms of the zoning of the indicators of dynamics and the rate of dynamics of land in municipal areas (Fig. 11).

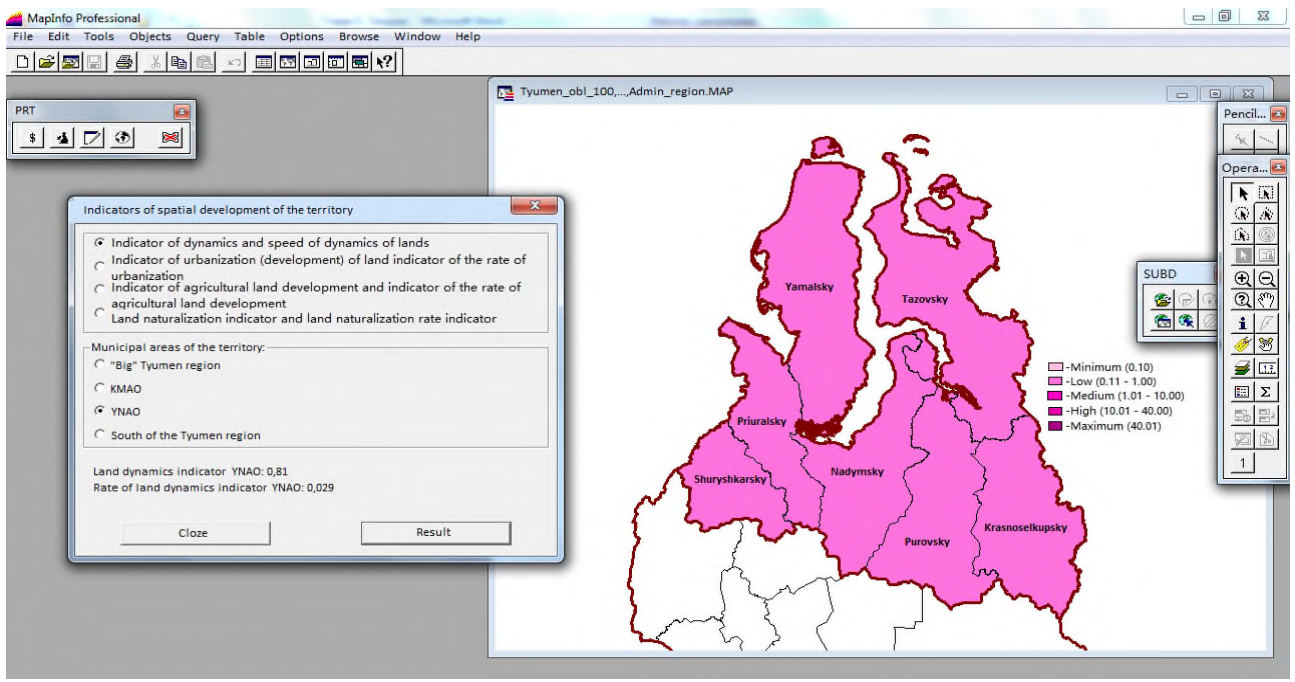

Fig. 11. Zoning of the territory according to the indicator of dynamics and the rate of dynamics of land in the municipal districts of the YNAO.

The indicator of the speed of land dynamics in all regions of the Yamalo-Nenets Autonomous Okrug varies from $0.18-0.36 \%$, which indicates a stable situation and insignificant quantitative changes.

The changes associated with the industrial development of its territory, the traditional economic activities of the indigenous population, the streamlining and establishment of the boundaries of settlements are obvious, but not significant in comparison with the south of $\mathrm{TO}$ and the entire region as a whole.

On the obtained cartogram of the south of TO, according to the zoning of the data on the indicator of dynamics and the rate of dynamics of the land of municipal areas, there are three sectors of bright pink illumination: Sorokinsky, Omutinsky and Berdyuzhsky municipal districts (Fig. 12). 


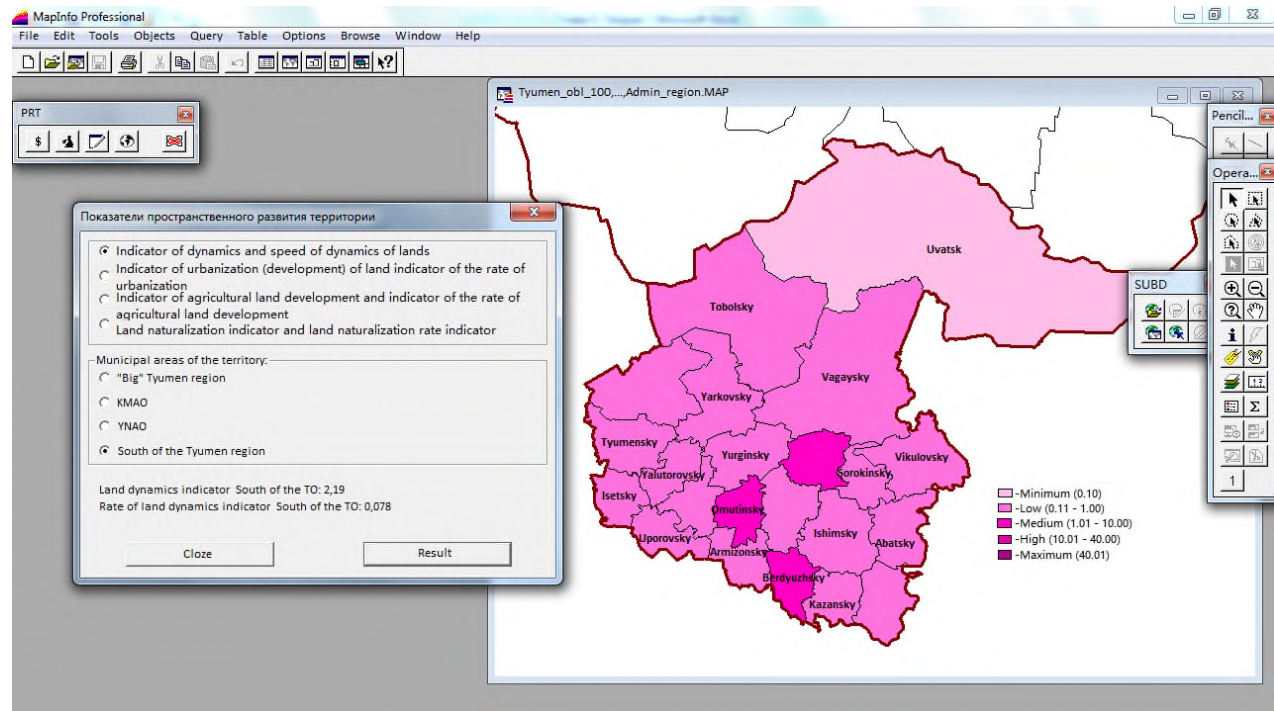

Fig. 12. Zoning of the territory according to the dynamics and speed of the dynamics of land in municipal areas of the south of TO.

Based on the obtained zoning, it is obvious that the Aromashevsky municipal district is distinguished by the highest percentage of the dynamics indicator in the presence of a significant speed of land dynamics. Nevertheless, within the accepted assessment scale, this indicator is at the lowest level of assessment. The smallest percentage is observed in the Uvat region $\left(\mathrm{P} \_\mathrm{dz}=0.08 \%\right)$.

Further, the call to Module 2 demonstrates the appearance of a window that allows you to select the parameters of the urbanization (development) indicator and the indicator of the urbanization rate of the "large" territory of TO (Fig. 13).

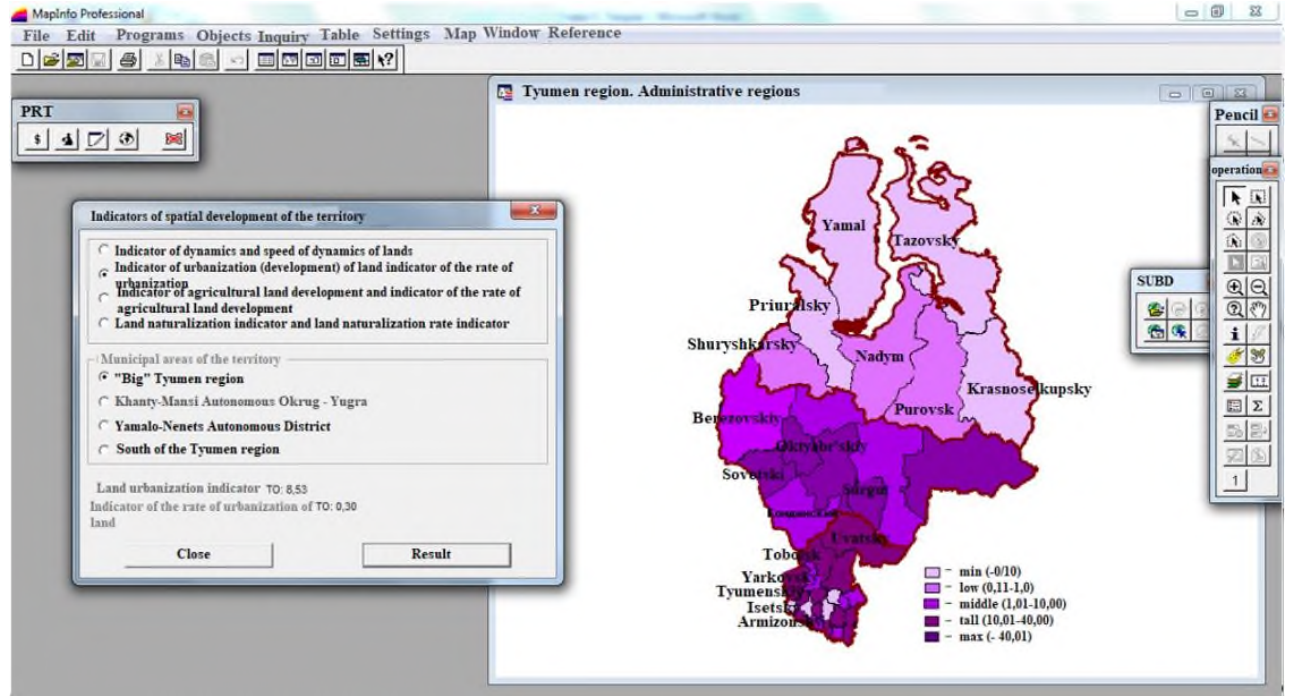

Fig. 13. Complicated subject "large" TO with display of the zoning of the territory according to the indicator of urbanization of land and the rate of urbanization. 
In terms of urbanization, the calculated figure shows that the situation in the region is in a state of greatest growth, the maximum quantitative changes in land use are observed, the spatial development of the territory is proceeding at a high rate.

Summarizing the results obtained, it should be noted that the region under consideration is characterized by a high level of urbanization, the concentration of a large number of the population in large cities. This is largely due to the predominance of large enterprises and deposits.

Figures 14-16 show cartograms built on the basis of generalized data entered into the MapInfo GIS database for each subject in terms of land urbanization and urbanization rate.

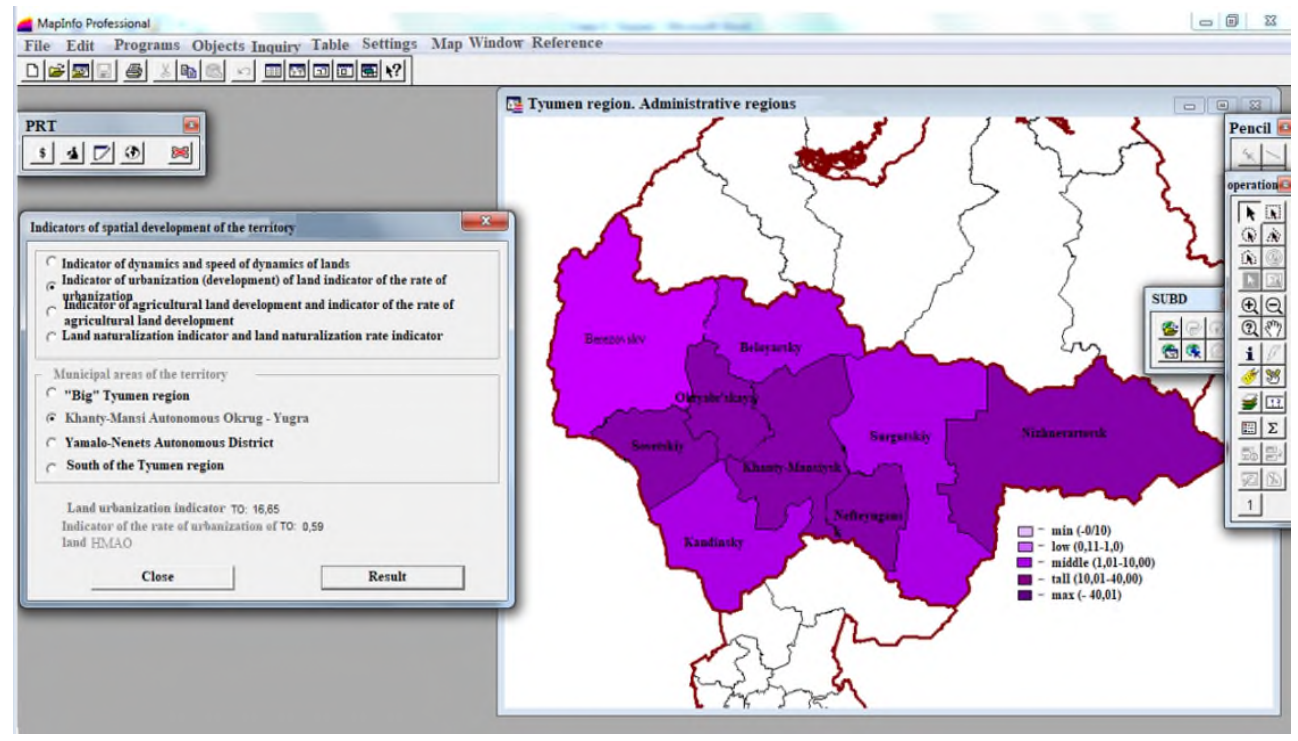

Fig. 14. Zoning of the Khanty-Mansi Autonomous Okrug according to the indicator of land urbanization and the rate of urbanization.

The most significant increase in urbanization (development) of land is noted in the Surgut (125.43\%), Oktyabrsky (72.45\%), Nefteyugansk (60.00\%) regions.

Such an increase in urbanization can be explained by the rapid development in the last decade of the raw material sector of the economy and the relatively high incomes of the population in these areas compared to the rest.

The resulting cartogram of the zoning of the Yamalo-Nenets Autonomous Okrug in terms of land urbanization and the rate of urbanization shows three sectors of bright pink illumination: Shuryshkarsky, Purovsky and Nadym municipal districts (Fig. 15). 


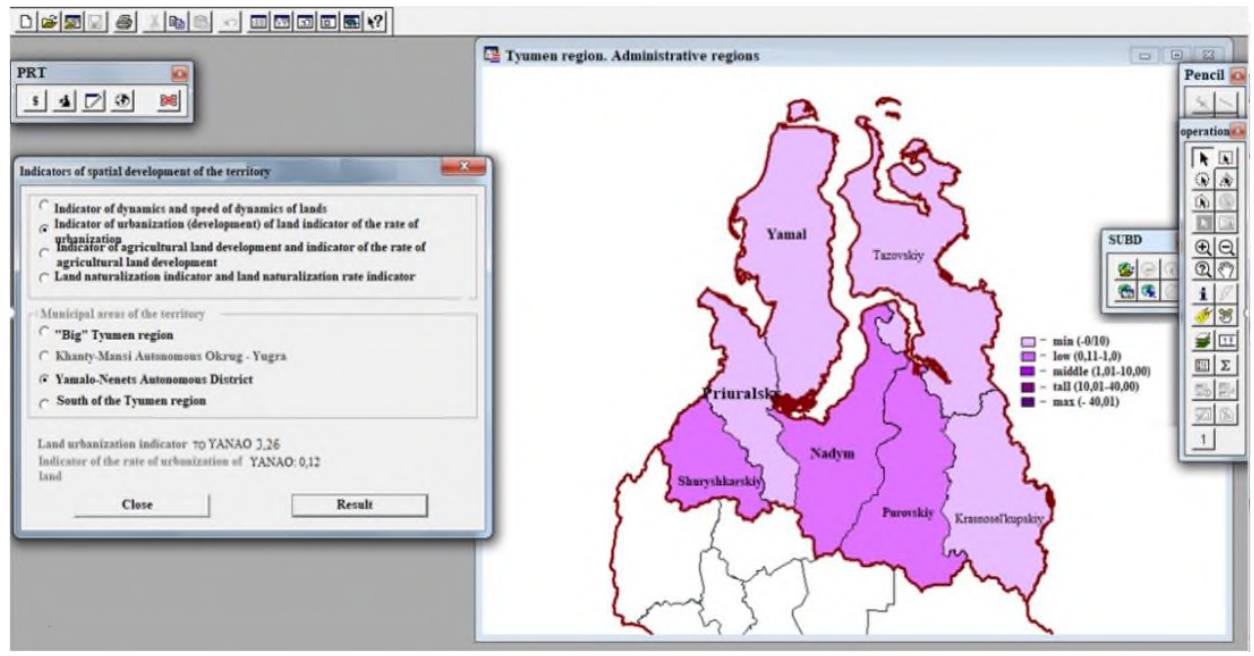

Fig. 15. Zoning of the Yamalo-Nenets Autonomous Okrug according to the indicator of land urbanization and the rate of urbanization.

As a result of the calculations, we obtained quite resonant values of the indicator of urbanization (development, development) of lands, an indicator of the rate of urbanization (development, development) of lands in all municipal districts of the Yamalo-Nenets Autonomous District.

The results obtained can be linked, first of all, with the low density of roads, inaccessibility, and climatic indicators of the regions.

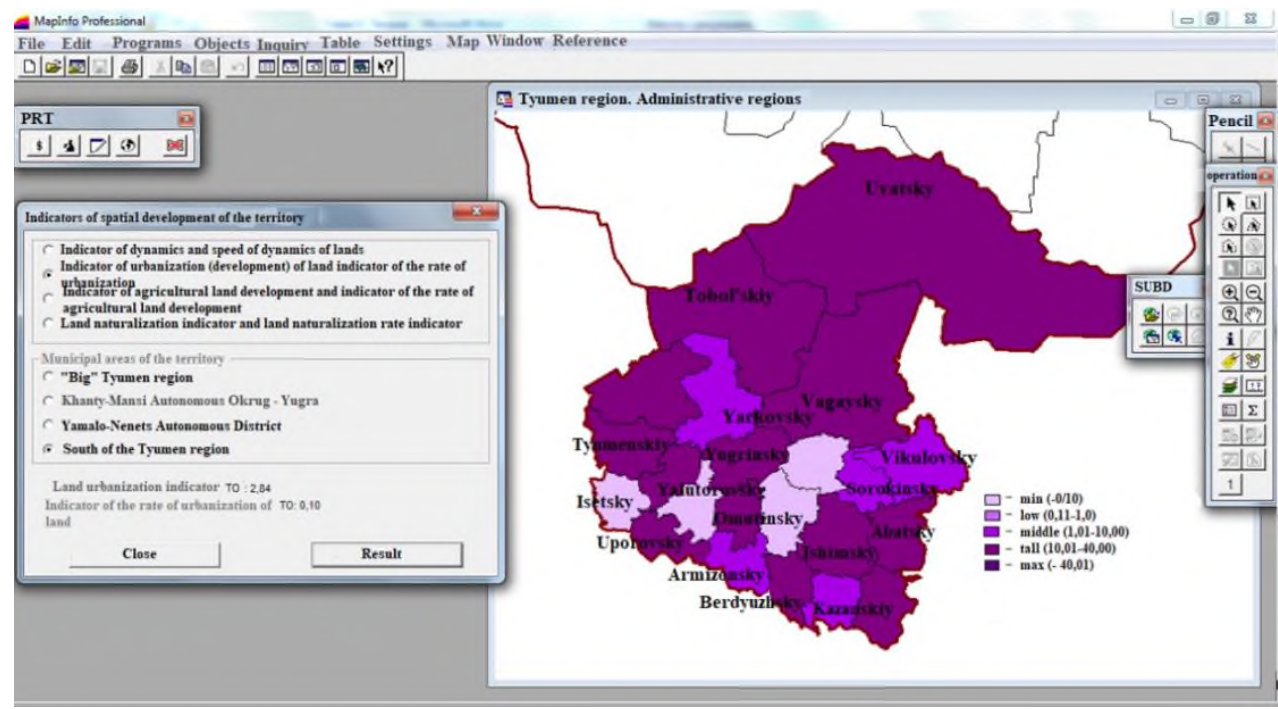

Fig. 16. Zoning of the territory of the south of TO according to the indicator of urbanization of land and the rate of urbanization.

According to the cartogram of the zoning of the territory of the south of TO in terms of land urbanization and the rate of urbanization, a very high degree of urbanization can be traced, there are many segments of dark purple dissemination (Fig. 16). 
The preponderance of the urban population over the rural is observed in most municipal districts, as a result of which the percentage of land development in the south is not great. The most highly urbanized municipal district was the Omutinsky district.

Following this, the call to Module 2 demonstrates the appearance of a window that allows you to select the parameters of the indicator of agricultural development and agricultural speed. development of lands of the "large" territory of TO (Fig. 17).

Figures 17-20 show cartograms built on the basis of generalized data entered in the MapInfo GIS database for each subject in terms of agricultural development and the rate of agricultural land development.

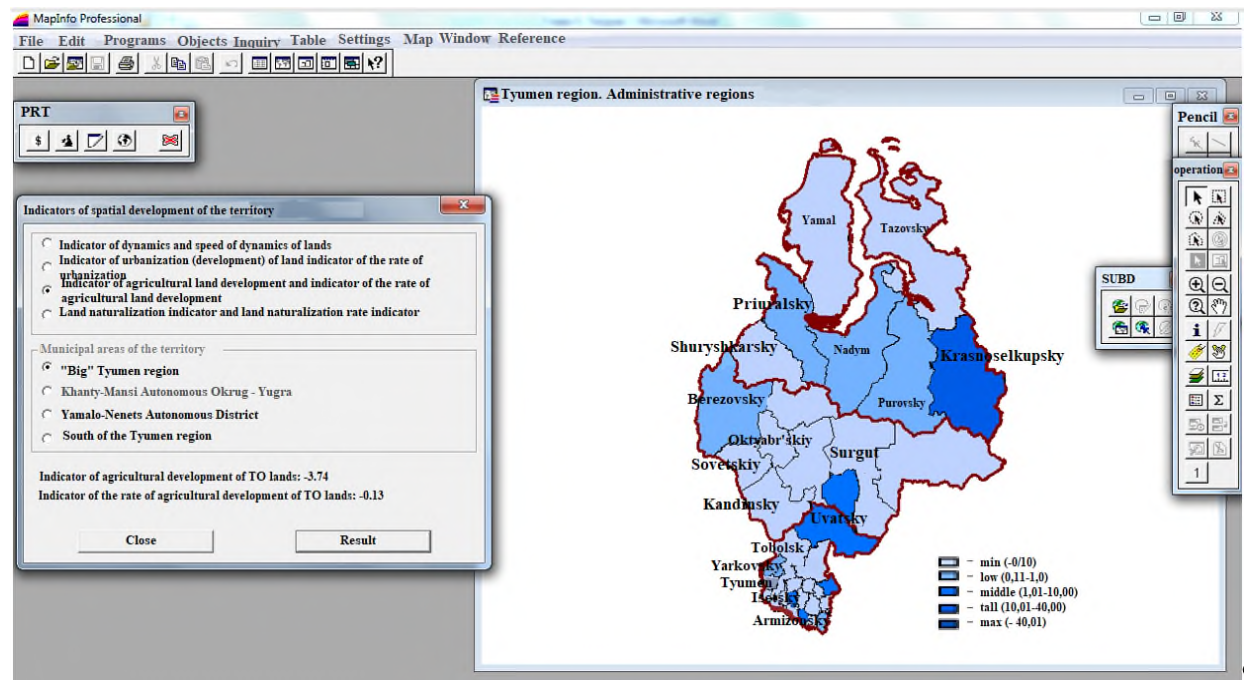

Fig. 17. Complex subject "large" TO with display of the zoning of the territory according to the indicator of agricultural development and the rate of agricultural land development.

By clicking on the "show the result" button, a cartogram is built for the selected indicator, visually reflecting the intensity of each indicator within the territory on the map.

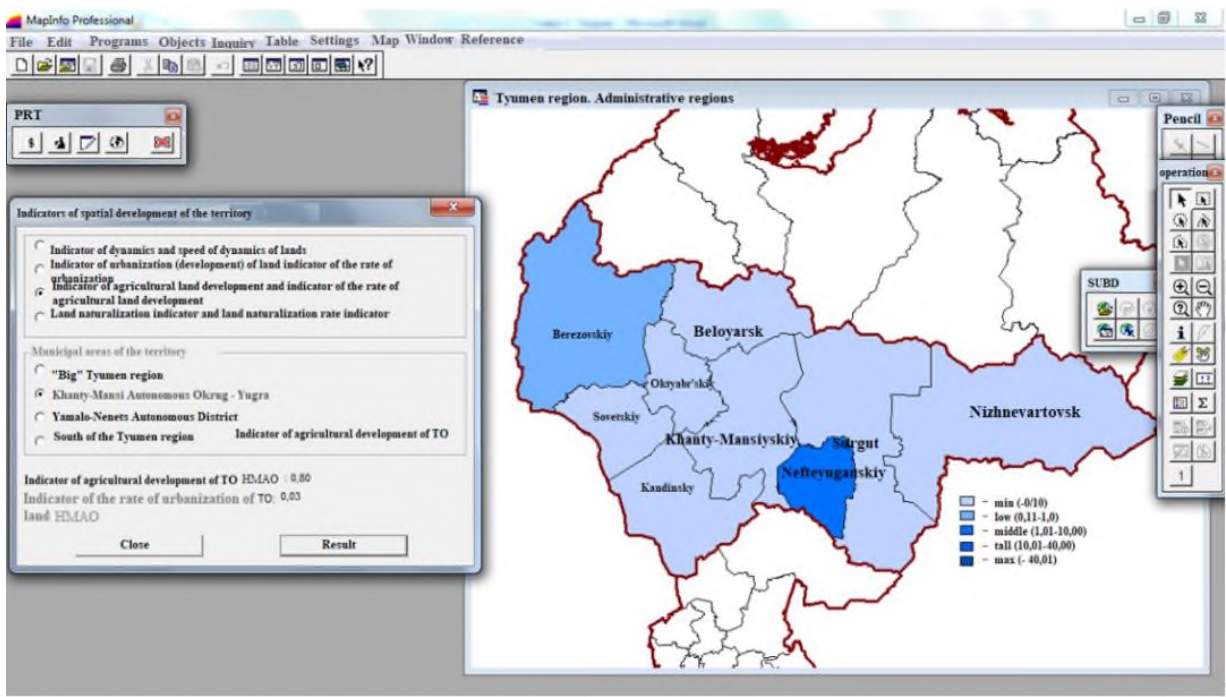

Fig. 18. Zoning of the Khanty-Mansi Autonomous Okrug according to the indicator of agricultural development and the rate of agricultural land development. 
Land targeting is observed everywhere in all municipal districts. The reason for this may be, among other things, the hydrographic network of the Khanty-Mansiysk Autonomous Okrug - Yugra, which belongs to the Kara Sea basin [1,2].

On the cartogram of the zoning of the territory of the Yamal-Nenets Autonomous Okrug in terms of agricultural development and the rate of agricultural land development, the Krasnoselkupsky municipal district stands out as a bright spot (Fig. 19).

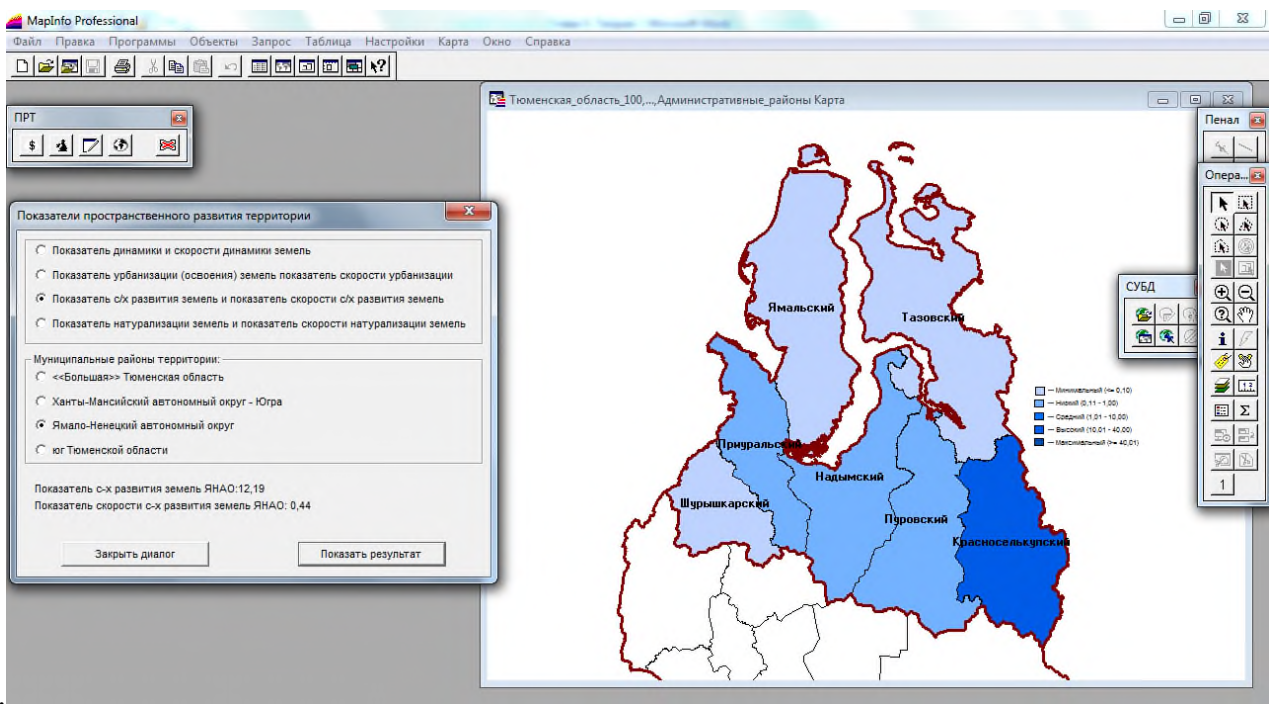

Fig. 19. Zoning of the Yamalo-Nenets Autonomous Okrug according to the indicator of agricultural development and the rate of agricultural land development.

The reason for such a low percentage of the indicator of agricultural development of lands and the indicator of the rate of agricultural development of lands (with the exception of the Krasnoselkup municipal district) may be the physical and geographical position of the Yamalo-Nenets Autonomous Okrug and its individual municipal districts.

The entire territory of the Yamalo-Nenets Autonomous Okrug belongs to the territory of the Far North (more than half of the territory is located beyond the Arctic Circle). Natural and climatic conditions of the Far North have a significant impact on the life of people, the development of the entire complex of industrial and social infrastructure $[3,4,5]$.

As a result of the analysis of the obtained cartogram of the zoning of the territory of the south of TO in terms of agricultural development and the rate of agricultural land development, it was established that the Uvatsky, Vikulovsky, Omutinsky and Berdyuzhsky municipal districts are the "leaders" from these positions (Fig. 20). 


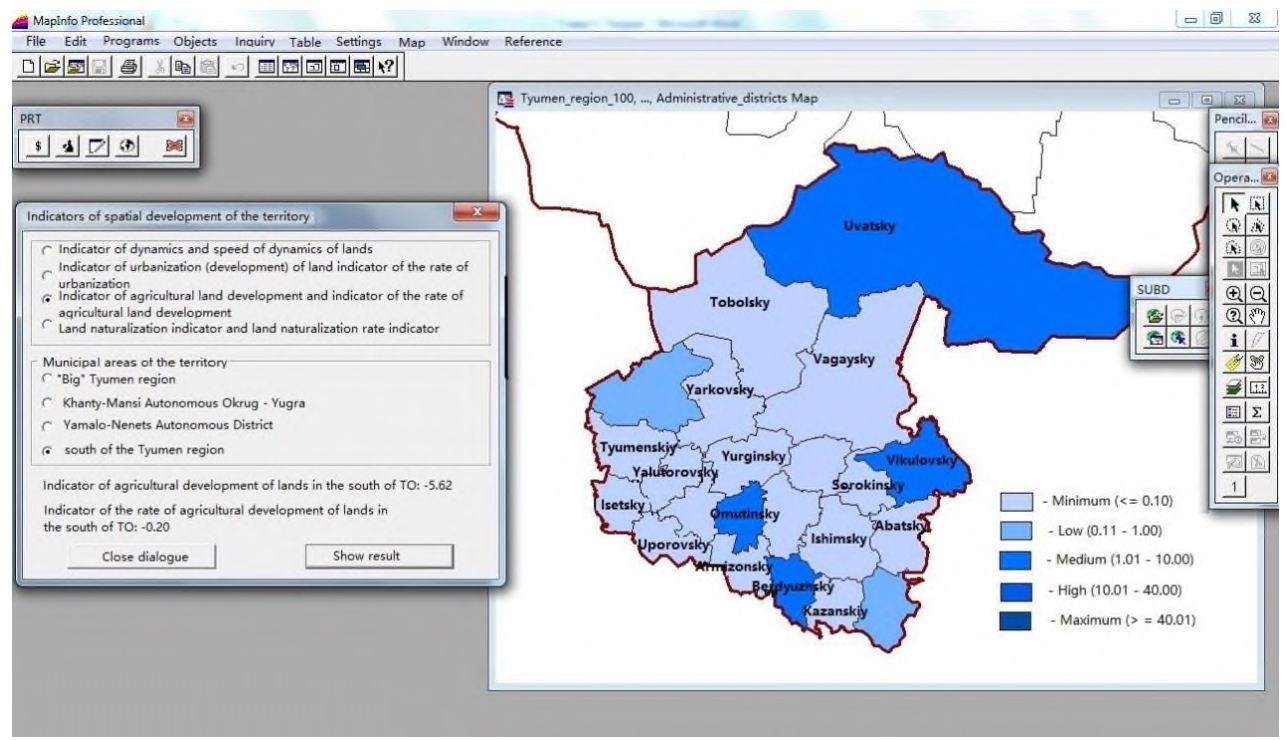

Fig. 20. Zoning of the territory of the south of TO according to indicator data agricultural development and the speed of agricultural land development.

The situation in terms of the indicator of agricultural land development and the indicator of the rate of agricultural land development is more than curious. The process of land goalization is observed everywhere. The highest percentage is observed in Uvatsky, Vikulovsky, Berdyuzhsky and Omutinsky districts.

The reason was the land reform of the early 90s, which, first of all, was aimed at changing social relations in rural areas through a rapid transition to private land ownership.

But at the same time, the issues of the efficiency of the use of land resources were overlooked, the prevention of their further degradation and retirement from agricultural circulation was not given due attention.

The final indicator of Module 2 is the indicator of land naturalization and the rate of land naturalization. Figure 21 shows the territory of a "large" TO with zoning according to the above indicator.

Figures 22-24 show cartograms built on the basis of generalized data entered in the MapInfo GIS database for each subject in terms of land naturalization and land naturalization rate. 


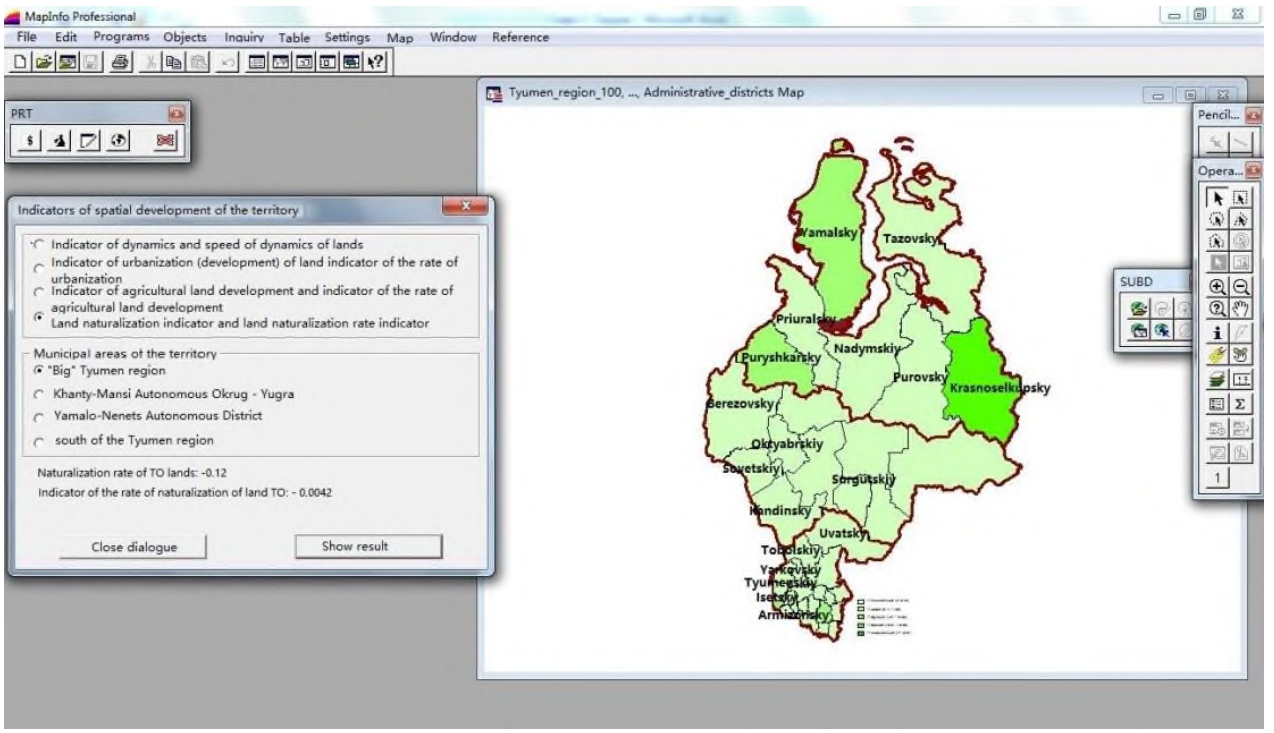

Fig. 21. Complicated subject "large" TO with the display of the zoning of the territory according to the indicator of naturalization of land and the rate of naturalization of land.

According to the cartogram of the territory of the Khanty-Mansi Autonomous Okrug within the framework of the zoning of indicators of naturalization of lands and the rate of naturalization of lands, it is clear that the situation in the subject is very favorable (Fig. 21).

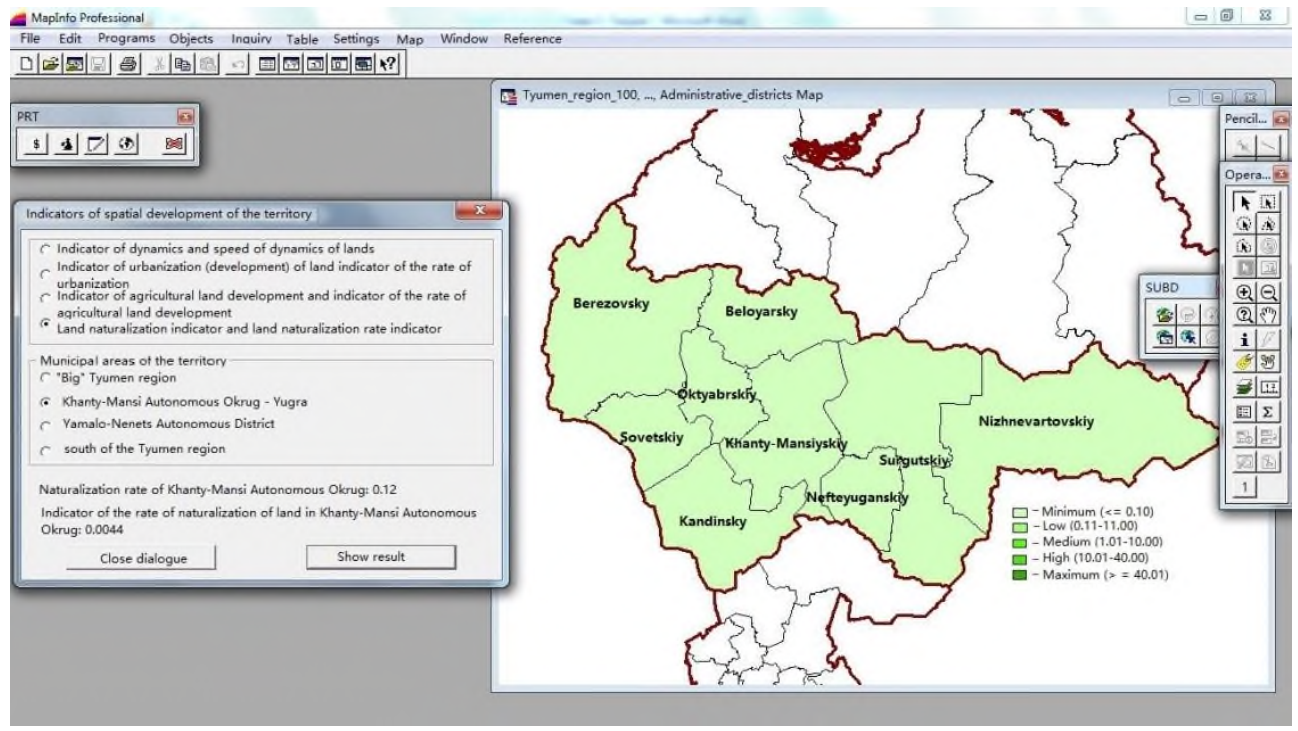

Fig. 22. Zoning of the Khanty-Mansi Autonomous Okrug according to the indicator of land naturalization and the rate of naturalization of land.

The indicator of land naturalization is presented in a rather positive way, since land deforestation is observed only in Nizhnevartovsk (-0.01\%) and Khanty-Mansiysk districts $(-0.01 \%)$.

In connection with the specifics of the geographical location of the region and individual municipal districts of the Khanty-Mansi Autonomous Okrug, when analyzing the 
use of forests in the Tyumen region, it is necessary to take into account the traditional use of natural resources by the indigenous peoples of the North $[6,7]$.

According to the cartogram of the Yamalo-Nenets Autonomous Okrug, within the framework of the zoning of indicators of naturalization of lands and the rate of naturalization of lands, both centers of "deforestation" and more "wooded" areas untouched by humans are visible (Fig. 23).

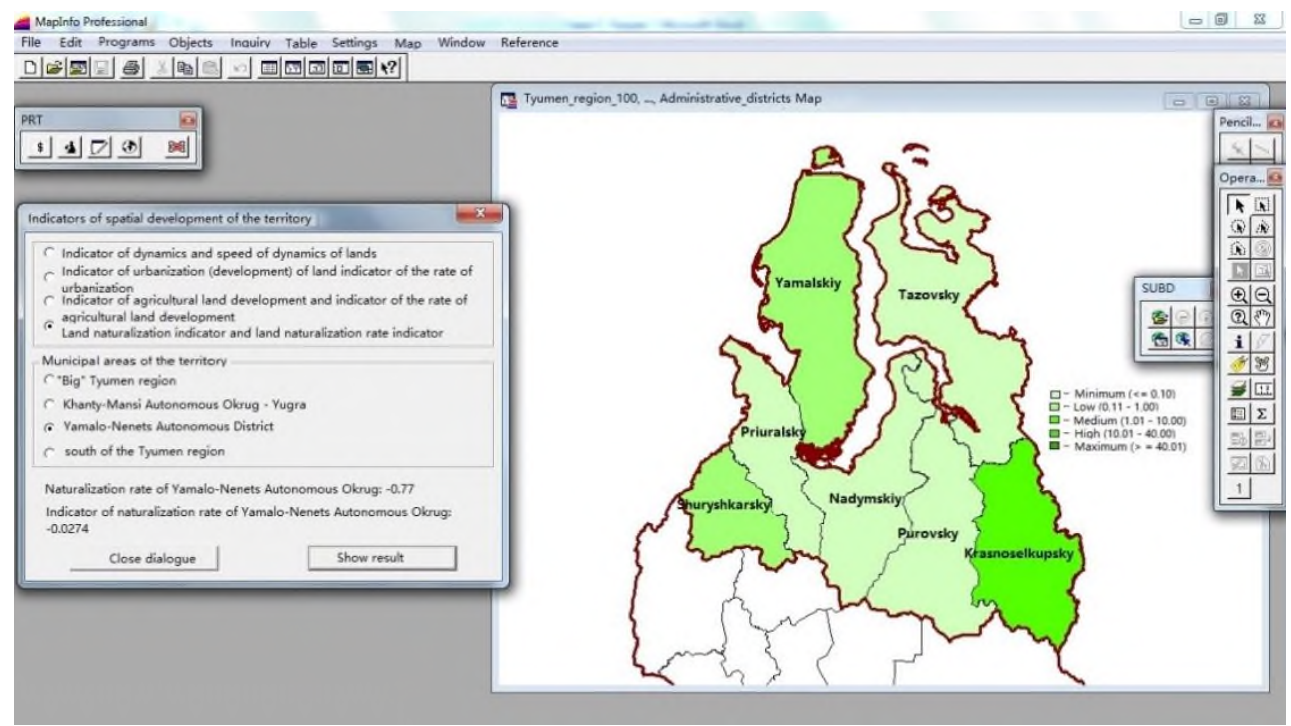

Fig. 23. Zoning of the Yamalo-Nenets Autonomous Okrug according to the indicator of land naturalization and the rate of naturalization.

Of the 7 districts of the Yamalo-Nenets Autonomous Okrug, 4 (Priuralsky, Purovsky, Tazovsky, Nadymsky) are evident processes of land deforestation, possibly difficult to eliminate.

The area of dead plantings in the Yamalo-Nenets Autonomous Okrug in recent years remains at a high level, there is an accumulation of areas of dead plantings for two reasons: drying out of plantations from fires of previous years and an insufficient amount of sanitary and recreational activities.

This is due, first of all, to the low density of roads and inaccessibility.

Analyzing the cartogram of the territory of the south of TO within the framework of the zoning of indicators of land naturalization and the rate of naturalization of land, it is necessary to draw a general conclusion about the presence of deforestation processes in 11 out of 22 municipal districts (Fig. 24). 


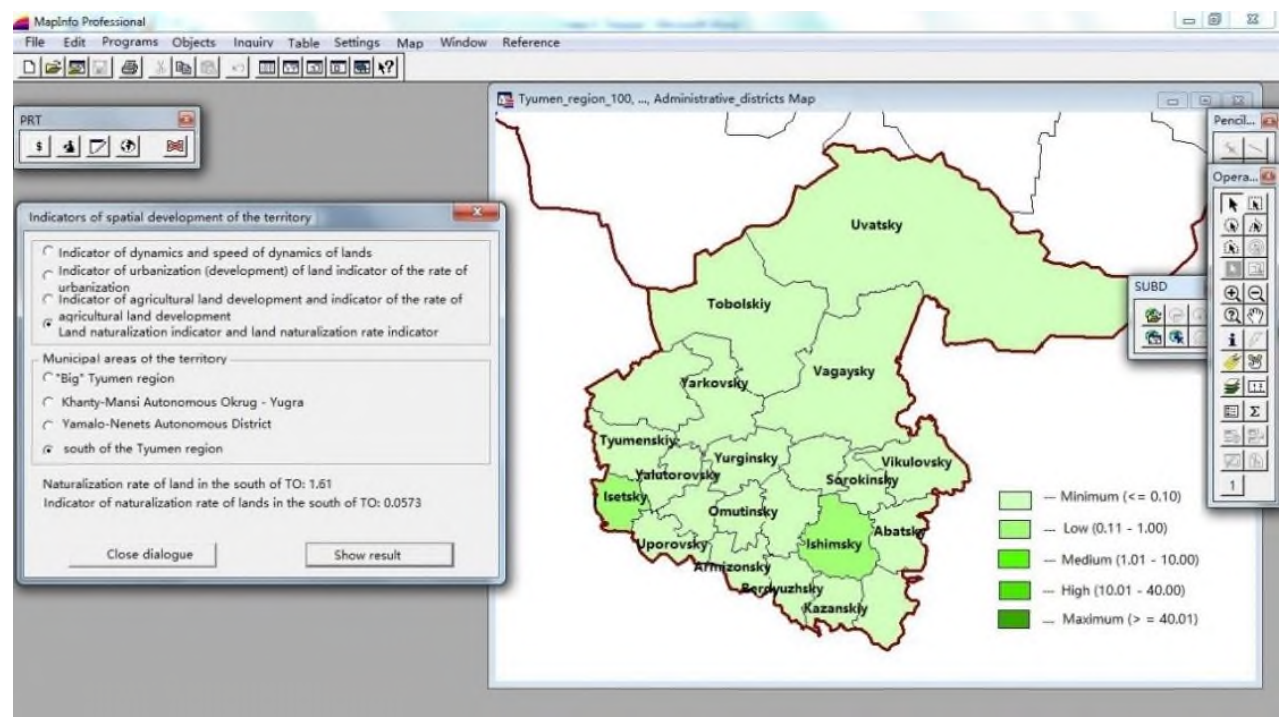

Fig. 24. Zoning of the territory of the south of TO according to the indicator of land naturalization and the rate of land naturalization.

The Nizhnetavdinsky, Ishimsky, Isetsky districts have the largest percentage of forest cover. After analyzing the data on the influence of groups of causes of plant damage, it can be concluded that the main cause of death and weakening of forest stands in recent years was fires. Unfavorable weather conditions and soil and climatic factors are the second most important cause affecting forest plantations.

\section{Results and discussion}

As a result of the functioning of the software complex, it was established that:

Module 1: None of the indicators and their combination during the period under review (2008-2018) returned to the previous state, which indicates the disequilibrium of processes in the economy.

Thus, it can be argued that the Tyumen region, exchanging significant flows of resources with the environment, is characterized as an open system with its own characteristics of territory management in a complex entity.

Unit 2:

1. On the obtained cartogram of the south of TO, according to the zoning of the data on the dynamics indicator and the speed of the dynamics of the land of the municipal districts, there are three sectors of bright pink illumination: Sorokinsky, Omutinsky and Berdyuzhsky municipal districts. Based on the obtained zoning, it is obvious that the Aromashevsky municipal district is distinguished by the highest percentage of the dynamics indicator in the presence of a significant speed of land dynamics. However, within the accepted rating scale, this indicator is at the lowest level of assessment. The smallest percentage is observed in the Uvat region $\left(\mathrm{P}_{-} \mathrm{dz}=0.08 \%\right)$.

2. The preponderance of the urban over the rural population is observed in most municipal districts, as a result of which the percentage of land development in the south is not great. The most highly urbanized municipal area was the Omutinsky District. The situation in terms of the indicator of agricultural land development and the indicator of the rate of agricultural land development is more than curious. The process of land goalization 
is observed everywhere. The highest percentage is observed in Uvatsky, Vikulovsky, Berdyuzhsky and Omutinsky districts.

3. The reason was the land reform of the early $90 \mathrm{~s}$, which, first of all, was aimed at changing social relations in rural areas through a rapid transition to private land ownership. But at the same time, the issues of the efficiency of the use of land resources were overlooked, the prevention of their further degradation and retirement from agricultural circulation was not given due attention.

4. The largest percentage of forest cover is in the Nizhnetavdinsky, Ishimsky, Isetsky districts. After analyzing the data on the influence of groups of causes of plant damage, it can be concluded that the main cause of death and weakening of forest stands in recent years was fires. Unfavorable weather conditions and soil and climatic factors are the second most important cause affecting forest plantations. Analyzing the cartogram of the territory of the south of TO within the framework of the zoning of indicators of naturalization of lands and the rate of naturalization of lands, we can draw a general conclusion about the presence of deforestation processes in 11 out of 22 municipal districts

\section{Conclusion}

The created software package ANDANTE 1.0 allows the user to solve a number of problems of systematization and primary processing of a large volume of spatial data on three subjects of the Tyumen region included in the static register of Rosstat for a given monitoring period in order to calculate and analyze indicators of spatial development of the territory of the "Big Tyumen region".

In addition, the ANDANTE 1.0 software package uses the established template in the form of data presentation, correlating the types of economic activities of three subjects: the South of the Tyumen region, Khanty-Mansi Autonomous Okrug and Yamalo-Nenets Autonomous Okrug, land areas of settlements and agricultural lands. The data is processed according to a given algorithm, including filtering (exclusion) processes from the general array of records for all subjects with signs of formal errors.

\section{References}

1. Order of the Government of the Russian Federation of 13.02.2019 N 207-r, http://static.government.ru/media/files/UVAlqUtT08o60RktoOX122JjAe7irNxc.pdf

2. Report "On the state and use of land in the Tyumen region in 2018", https://rosreestr.ru/site/activity/sostoyanie-zemel-rossii/gosudarstvennyy-natsionalnyydoklad-o-sostoyanii-i-ispolzovanii-zemel-v-rossiyskoy-federatsii/

3. J.M. Bryson, F.K. Alston, Creating and implementing your strategic Plan: A workbook for Public and Nonprofit Organizations (Jossey-Bass, 2004)

4. M. Allison, J. Kaye, Strategic Planning for Nonprofit Organizations: A Practical Guide and Workbook (John Wiley and Sons, 2005)

5. Decree of the President of the Russian Federation "On the regulation of land relations and the development of agrarian reform in Russia" No. 2287 (1993)

6. Decree of the President of the Russian Federation "On the State Land Cadastre and Registration of Documents on Rights to Real Estate" No. 2130 (1993)

7. Resolution of the Governor of the Tyumen region "On the regional program" Development of land reform in the Tyumen region for 2000-2002 No. 88 (2000) 